\title{
接触場面における香港の日本語学習者の意識 ービジネス接触場面において学習者が感じた問題を中心に一 Awareness of the problematic situations at contact situation of Japanese learner in Hong Kong
}

\author{
粟飯原 志宣 \\ 香港大学専業進修学院 \\ 早稲田大学大学院博士後期
}

\section{要旨}

本稿では、ビジネス日本語教育現場の改善を提言するために、面接調查で得られた香港のビジネ ス接触場面における非日本語母語話者（5名）の意識 66 件を 9 項目に分類し、詳細に考察した。そ の結果、非日本語母語話者は(1)ビジネス表現・用語／名詞修飾／要約力等の言語能力強化、(2)対照 言語行動に関する問題解決、および(3)ビジネス接触場面の背景知識（日本的企業文化等）が必要で あると再確認された。また、(4)待遇表現の面で日本人に対して不快感を抱いていることも明らかに なり、異文化コミュニケーションに向う日本人に対する警鐘となろう。今回の面接調查により非日 本語母語話者の問題意識は日本人同様、対照言語行動に関する内容が多く、教育内容として需要で あることが示唆されている。 


\section{接触場面における香港の日本語学習者の意識 \\ ービジネス接触場面において学習者が感じた問題を中心に一}

\section{粟飯原 志宣 \\ 香港大学専業進修学院}

\section{1.はじめに 本稿の背景と目的}

実務で中国語や英語など母語以外でビジネスに携わると、言語形式の学習では解決できない問題 があると感じる。筆者は、ビジネス接触場面の参加者が問題だと意識した内容を詳細に調查し、解 決のための教育内容として提示することで、ビジネス日本語教育現場の改善を目的としている。本 稿では、日本語ビジネス接触場面で香港の非日本語母語話者が問題として意識した内容についての 基礎調查の経過と現時点における分析を報告したい。

\section{2. 先行研究}

ビジネス日本語教育は、異文化コミュニケーションの典型的な一場面であるが、紙面の関係上、 ビジネス接触場面関連の先行研究についてのみ述べる。日本では、近藤（1998）の日本で働く外国 人ビジネス関係者が接触場面で持つ問題を四つの因子に分けた考察や、清（1998）が行った外国人 社員と日本人社員とのコミュニケーションの阻害要因を双方から調查等があげられる。本稿の調查 地香港の研究では、宮副に多く、特に宮副（2003）では、多言語職場における会話で生じている理 解のずれを接触場面の参加者全員の視点から詳細に述べている。粟飯原（2008）では、仕事で日本 語を使う日本語学習者 62 名に対するアンケートから抽出した「問題として意識したこと」 83 件を 接触場面の種類別、問題の内容別、問題に対する自覚の有無という 3 つの視点から分析している。 表 1 は、そのうちの問題を内容別に分類したものを筆者がまとめたものである。

表 1 学習者がビジネス接触場面で意識した問題（アンケートに見られる代表的な内容）

\begin{tabular}{|c|c|c|c|}
\hline 分類項目 & 割合 $\%$ & 件数 & アンケート調査結果の内容 \\
\hline 言語形式 (文法. 語彙等) & 32.5 & 27 件 & 狭義の敬語文法、専門用語、ビジネスに使われる表現、文法全域 \\
\hline 聴解 (語彙. 話す速度) & 12.0 & 10件 & 白本人は早口なので聞き取れない/聞いてもわからない言葉が多い \\
\hline 発音 & 1.2 & 1 件 & 聞き取ってもらえない \\
\hline 産出に困難. 不安を感じる & 31.3 & 26 件 & 白本人と話寸時、繁張して覚えた日本語が出てこない／妘えたいことが相手に伝 \\
\hline 対照言語行動. 異文化理解 & 16.9 & 14件 & 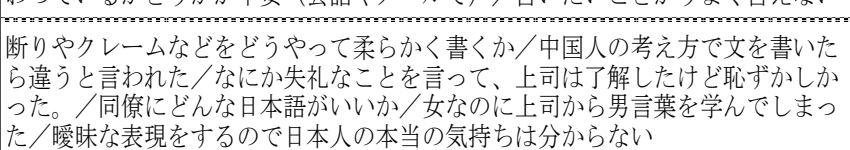 \\
\hline 実務.ビジネススキル & 6.0 & 5 件 & $\begin{array}{l}\text { (以下の項目が分からない) プレゼンテーションの仕方／報告のしかた／交渉の } \\
\text { しかた/ビジネスマナー／電話の取り次ぎ／翻訳・通訳の注意点 }\end{array}$ \\
\hline 合計 & 100.0 & 83 件 & \\
\hline
\end{tabular}


粟飯原（2008）では、「学習者は主に話す場面（56.7\%）と聞く場面（24\%）で問題を意識して いる。その内容として、(1)狭義の敬語文法や基本的文法知識、ビジネスに必要な語彙や定型表現、 業務に必要な専門用語といった言語能力不足。(2)こうした知識不足や言語能力に対する自信のなさ から、会話や電話などで、聞き取りや日本語の産出に困難や不安を感じている。一方(3)対照言語行 動、異文化理解に関する問題意識は、日本語母語話者ビジネス関係者の言語行動に関する意識 $73 \%$ 弱 に比較するとかなり少ない。(4)実務、ビジネススキルについては、学習者は日本語でビジネススキ ルを発揮して遂行するような実務はまだ任されていないため、問題意識としてあがってきていな い」と指摘している。しかし、上述からは学習者像の大まかな傾向は把握できても、教材化できる 学習者の視点からの具体的な内容は窺えない。粟飯原 (2009)では、日本語母語話者側が問題だと意 識した内容 45 件、粟飯原（2012）では 175 件の分析が行われているが、ビジネス接触場面で発生 する問題を解決するには、日本語母語話者と非日本語母語話者双方からの基礎データが必要である。 そこで本稿では、ビジネス日本語教育現場の改善を提言するための足がかりとして、非日本語母語 話者の意識を探る基礎調査を行い、詳細な分析を試みた。

\section{3. 調査協力者ならびに研究方法}

2011 年 1 月から、日本語で業務に携わる香港の非日本語母語話者ビジネス関係者（以下、FJ と略 す）に平均 2 時間の半構造化面接を行っている。協力者の選択にあたっては、アンケートでは得ら れなかった具体的な内容を収集するため、取引先との対外的交涉を任せられる上級レベルであり、 年齢、業種、職種、性別も偏らないように配慮している。面接内容は許可の上、録音・文字化し、 そこから FJ が業務に関わることで感じた様々な内容を基礎データとして抽出し、 $\mathrm{KJ}$ 法 ${ }^{1}$ を参考に分 類した。本稿では、2011 年 6 月時点で面接済みのFJ 5 名の基礎データをもとに、アンケート結果の 修正・精密化に向けた中間報告を行う。

表 2 粟飯原（2008）のアンケート調査の対象 62 名の学習者のプロファイル

\begin{tabular}{|c|c|c|c|c|c|c|}
\hline 日本語レベル & 4 級 & 3 級 & 2 級 & 1 級 & 未回答 & 合計 \\
\hline & 1 & 5 & 29 & 20 & 7 & 62 \\
\hline \multirow[t]{2}{*}{ 学習期間 } & 2 年末満 & 2 年以上 & 5 年以上 & 10 年以上 & 未回答 & 合計 \\
\hline & 5 & 26 & 28 & 2 & 1 & 62 \\
\hline \multirow[t]{2}{*}{ 留学経験の有無 } & $\begin{array}{l}\text { 無 } \\
\end{array}$ & 有 ( 1 年未満) & 有 ( 1 年以上) & 有 ( 3 年以上) & 未回答 & 合計 \\
\hline & 21 & 4 & 12 & 3 & 23 & 62 \\
\hline 日本語で話す相手 & 上司 & 同僚 & 部下 & 取引先 & 未回答 & 合計 \\
\hline （複数回答） & 44 & 30 & 2 & 36 & 4 & 116 \\
\hline 学習動機 & (1) & (2) & (3) & (4) & 合計 & \multirow{5}{*}{$\begin{array}{l}\text { (1)就職のため } \\
\text { (2)仕事で必要 } \\
\text { (3)文化に興味 } \\
\text { (4)その他 }\end{array}$} \\
\hline 開始時 & 10 & 8 & 45 & 4 & 67 & \\
\hline 現在 & 11 & 53 & 12 & 3 & 79 & \\
\hline BJ学習経験の有無 & 無 & 有 & 未回答 & 合計 & & \\
\hline & 45 & 15 & 2 & 62 & & \\
\hline
\end{tabular}




\section{粟飯原 志宣：接触場面における香港の日本語学習者の意識}

ービジネス接触場面において学習者が感じた問題を中心に一

表 3 香港で日本語を使用して業務に携わる非日本語母語話者（FJ）５名のプロファイル

\begin{tabular}{|c|c|c|c|c|}
\hline & 業種 & 職責 & 日本語使用年数 & 学習歴 \\
\hline & \multicolumn{4}{|c|}{ 日本語使用場面 } \\
\hline \multirow{2}{*}{$\begin{array}{c}\text { FJ } 1 \\
\text { 女性20代 }\end{array}$} & 外資系金融 & カスタマーサービス & 3 年（香港） & 大学（日本語専攻）日本留学 1 年 \\
\hline & \multicolumn{4}{|c|}{ 英和翻訳（投資商品のパンフレット、説明文）、メールでの取引先, 個人顧客とのやり取り全般 } \\
\hline \multirow{2}{*}{$\begin{array}{c}\text { FJ } 2 \\
\text { 女性 } 30 \text { 代 }\end{array}$} & 日系信用会社 & 秘書 & 6 年 $($ 香港 $)$ & 高校から短大まで独学 \\
\hline & \multicolumn{4}{|c|}{ 対面の会話、電話、メールによる上司や取引先との日常業務全般と日中翻訳 } \\
\hline \multirow{2}{*}{$\begin{array}{c}\text { FJ } 3 \\
\text { 女性20代 }\end{array}$} & 政府関連機関 & イベント管理 & 2 年 (シドニー) 1 年半 (香港) & 高校から独学、大学（日本語専攻） \\
\hline & \multicolumn{4}{|c|}{ 上司や日本の本部や支部との電話、対面、メールによるやり取り全般、イベント会場来場者への対応および日英翻訳 } \\
\hline \multirow{2}{*}{$\begin{array}{c}\text { FJ } 4 \\
\text { 男性 } 20 \text { 代 }\end{array}$} & 日系機械 & 営業 & 3 年 (香港) & 大学 (日本語専攻) 日本留学 1 年 \\
\hline & \multicolumn{4}{|c|}{ 商談や技術レベルの翻訳・通訳。電話、対面、メールによる社内、社外とのやり取り全般。 } \\
\hline \multirow{2}{*}{$\begin{array}{c}\text { FJ } 5 \\
\text { 男性40代 }\end{array}$} & 日系薬品 & 本社国際部副部長 & 20年 (香港) & 日本留学 (大学、大学院) \\
\hline & \multicolumn{4}{|c|}{ 本社との連携（報告書、会議、プレゼン等）。中国の取引先と本社の間の通訳・翻訳 } \\
\hline
\end{tabular}

\section{4. 調査結果と考察}

\section{1 張の調査の観察}

FJ 5 名に対する面接調査からは 66 件の具体的な問題内容（基礎データ）が得られた。基礎データ はまず、表 1 に従い分類し、そこに分類し切れなかった内容や、アンケートには見られなかった特 徵ある内容には、新たに 3 項目を追加した（表 4）。4.1 では、アンケート調查結果との比較分析を、 4.2 では、新たに追加した 3 項目について説明を加える。

表 4 FJ がビジネス接触場面で意識した問題の項目（面接調查）

\begin{tabular}{|c|c|c|}
\hline \multirow{2}{*}{ 分類項目 } & \multicolumn{2}{|c|}{ アンケート } \\
\hline & 割合\% & 件数 \\
\hline 言語能力（文法. 語彙等） & 32.5 & 27 件 \\
\hline 聴解（語彙. 話寸速度） & 12.0 & 10件 \\
\hline 発音 & 1.2 & 1 件 \\
\hline 産出に困難、不安を感じる & 31.3 & 26件 \\
\hline 実務／ビジネススキル & 6.0 & 5 件 \\
\hline 対照言語行動／異文化理解 & 16.9 & 14件 \\
\hline JJに対する不快感 & - & $-\ldots$ \\
\hline ビジネス接触場面の背景 & - & - \\
\hline 期待する/役に立つた教育的補助 & - & - \\
\hline 合計 & 100.0 & 83件 \\
\hline
\end{tabular}

\begin{tabular}{|c|c|c|}
\hline \multicolumn{2}{|c|}{ 面接調査 } & \multirow{2}{*}{ 面接調査結果の内容 } \\
\hline 割合\% & 件数 & \\
\hline 19.7 & 13件 & 長文、専門用語、表現、敬語、母語との表現上の違い等 \\
\hline 4.5 & 3件 & 専門用語 \\
\hline 0.0 & 0 件 & - \\
\hline 0.0 & 0件 & - \\
\hline 7.6 & 5 件 & 自分の携わる業務・業界の専門知識、ビジネススキル \\
\hline 34.8 & 23 件 & 職務範囲、評価、謝罪、価值観、定型表現、曖昧さ、マナー、待遇表現 \\
\hline 15.2 & 10件 & 文化の押しつけ、メール、待遇表現、接触場面への覚悟 \\
\hline 10.6 & 7件 & 日系企業側: FJ1-17, FJ2-4.6.10, FJ3-14, 香港側:FJ1-16.19 \\
\hline 7.6 & 5件 & 企業へ:FJ1-18.25 教育機関へ:FJ-22.23.24 \\
\hline 100.0 & 66件 & \\
\hline
\end{tabular}




\section{2 アンケート調查結果との比較分析}

表 4 の分類項目のうち、<言語能力 $><$ 聴解 $><$ 産出に困難、不安 $><$ 実務・ビジネススキル $>$ <対照言語行動・異文化理解 $>$ のつの項目において、アンケート調查と面接調查の結果の比較分 析を通し、接触場面で FJ が抱える問題の具体的内容を探る。

\subsection{1 基礎的言語能力（19.7\%）}

アンケートでは「狭義の敬語、専門用語、ビジネスで使われる表現、文法全般」が問題項目として あげられ、面接調查結果でも、概ねアンケート調査の内容を具体的に補足する形で収集された。し かし、アンケートでは $32.5 \%$ であるが、面接調査では文法に関する問題意識が全く見られないため に $19.7 \%$ とかなり低い。FJ が文法事項を問題として取り上げていないのは、実務経験から、JJ が 言語形式的な間違いをさほど気にしておらず、それが重大な問題にはならないことに気づいたから ではないだろうか。他言語使用に不慣れな段階では、問題を意識した時、まず原因を自分の基礎的 言語能力不足に求める傾向が見られる。それでアンケート調査では「文法事項」が高い割合となっ たが、面接調查では、具体的な内容が語られ、文法以外の項目に再分類できたため、大幅に下がっ たと考えられる。

以下具体的な内容として、語彙、敬語、長文、文法について、FJの言葉を引用する。

FJ1-21 本当にすぐ使える、文章。なんでした‥クッションワード、それが知らなかったんで、なんか程度があって、なんか強い・弱 い全然知らなかったんです。

FJ42 たまに技術の面の打ち合わせもあるので、例えばサプライヤーさんの工場に行って製品の技術についていろいろな面の言葉、 やっぱり勉強不足で詳しくないんで、専門用語。

く基礎的言語能力>で教育内容として重要なのは、まず専門用語、言い回し、クッションことば 等の語彙・表現である。ビジネス的言い回しやクッションことばなどについてはテキストもあり、 ある程度授業でもできる。しかし、多種多様な職種の専門用語を教室で学習するのは、インハウス のビジネス日本語教育でない限り難しく、教室では学習者が個別に必要な情報を得るための自律学 習方法が重要な教育内容となろう。

FJ34＼cjkstart最初のときはなんか普通の日本語でしやべったんですけど、敬語使わないと、なんかヤバイかなって思ったんですけど。あた しの部門では敬語は使ってないです。ただ、私の部門以外の人たち、例えば私の上司が所長と話したら、やっぱりもうちょっと丁寧に 話すんですよ。あと、メールのやり取り見てて、みんな敬語を使っていて、私だけが敬語を使わないとなんか、まあ、私が香港人だと みんなが分かると思うんですけど、でもやっぱり使わないと良くないかなって思ったんです。 


\section{粟飯原 志宣：接触場面における香港の日本語学習者の意識 \\ ービジネス接触場面において学習者が感じた問題を中心に一}

次に多いのが敬語文法に対する問題意識である。粟飯原（2008）で上級日本語学習者に行った敬 語クイズの結果は、基本的敬語文法の欠如を示しており、上記に見られる敬語に対するFJ のニーズ を満たすには、待遇表現や配慮表現なども丁寧さに不可欠な要素であるが、上級学習者でもまず、 狭義の敬語文法から学習し直さなければならないことが窥える。

\begin{tabular}{|c|}
\hline $\begin{array}{l}\text { FJ47 長い文の日本語は切り方がちょっと微妙、曖昧なところがあるんですよ。それで長い文章だと、どこで切って、一部一部を分 } \\
\text { 解したほうがいいかなと思ったりして。 }\end{array}$ \\
\hline
\end{tabular}

さて、アンケートでは見られなかった内容に、上記のような長文の産出と理解に対する苦手意識 があげられる。粟飯原（2008）では、FJ は JJ から長い文を読み書きする業務をあまり期待されて おらず、「書く」ことに対する問題意識も低い。しかし本稿の面接調查の協力者のように対外交涉 を求められるFJ には必要な言語能力である。長文の理解・産出能力の養成には名詞修飾の熟知と要 約力の強化が求められる。

FJ3-10 「途中に同僚に代わってもらったので詳しく分かりません。途中までわかんないんですよ。私最後まで分からないから。」と 言ったら誤解されたんです。こういう誤解がすごく多いんですよ。

この項目の冒頭で、FJ の文法に対する問題意識が薄れていると述べたが、実は上級日本語学習者で も不安定な助詞の使い方が、JJ との間に大きな感情的距離を生む例もあり、文法事項はおろそかに できないという意味を込めてこの事例を取り上げた。この事例では「途中までしか分からない」と いうべきところを「しか」が抜けて「途中まで分かんないんですよ。私最後までわからないから」 という意味不明の文になっている。後述 FJ3-11 にある「所長に私を呼んだんです」も同様である。 またFJ3 は同僚の話をしている流れのままで、同じテーマで自分の話に変わっているケースも見 られ、聞き手 (筆者) がその話の主語が変わっていることに気づいたときには、これまでの理解を 瞬時に再構築しなければならず、聞き手に負担を与える。この場合は「同じケースで、私の話です が」とか「そういえば」とか話の展開を明示するメタ言語表現が必要である。このように助詞の混 乱や、言葉足らずが原因で聞き手に負担を掛けていることを、FJ3 本人は気がついておらず、逆に JJ を「こういう誤解」をする人と批判的に見るという人間関係上の問題に発展している。 


\section{2 .2 聴解「早ロで聞き取れない、分からない言葉が多い」（4.5\%）}

この分類項目は、アンケートでは $12 \%$ と比較的に高く、FJ が意識する問題として項目化したが、 ここでは面接調査の協力者の日本語能力は既に高いせいか、 $4.5 \%$ とかなり低い。

FJ3-6 時々寸ごい難しい日本語を使っていて分からないです。例えば、あの、講演するとき?その時、私が聞いたらだいたい分かる んですけど、詳しくは分からないです。専門用語が分からないです。

FJ4-5＼cjkstart時に向こうの話すスピードが速くて、追いかけないんで、もう質問もできないんですね。

しかし、そうしたレベルでも、専門用語が分からないため、あるいは相手によっては早くて聞き 取れないと語っている。専門用語に関してはく言語能力>で述べたように自律的学習方法を指導す ることで補うが、特に海外では自然な日本語を聴く機会が限られているので、聴解練習には日本国 内での学習よりも工夫が要求される。

\subsection{3 産出に困難、不安を感じる（0\%）}

アンケート調査結果では $31 \%$ 強もあるが、面接調查では、この項目に対応するデータは得られな かった。しかしそれは、FJ の日本語能力が高いから困難や不安がなくなったことを意味するわけで はない。産出に対する困難や不安には必ず原因がある。FJ 自身がそれを明確に表現できない場合、 この項目や原因を「文法項目」に求めたと考えられる。この項目が０\%になったのは、面接調查に おいて、不安の原因が、名詞修飾や定型表現等教育内容として分類できるまで詳しく語られ、他の 項目に再分類できたためではないだろうか。

\section{2 .4 実務、ビジネススキル $(7.6 \%)$}

ここには実務能力にかかわる問題を分類した。直接的には、専門用語などの語彙力、聴解力、JJ の曖昧な表現といった基礎的言語能力に起因する問題である。しかし「確認」という基本的なビジ ネススキルを実行していれば、起きなかった問題である。

FJ1-13 けっこう言われたのは、電話してからメールするようにと、けっこう言われた。私はあまり日本語が上手じやないから、聞き 取りが間違ったりするかもしれませんので、絶対メールで確認をして。最初は 1 回、2 回ぐらいは確認しなかったんで、結構大変なこ とになっちゃったんで。（何か数字の間違いとか?）じやなくて、電話でサンプルの送りが遅れるかもしれませんという電話をしまし たけど、でもメールがしなかったから、たぶん一日ぐらい遅れたんですね。それでお客さんがすごく怒って、「なんで遅れるの、メー ルもしないで」って。（電話したのに？）そうです。でも、たぶん、そのときは働き始めたばかりで、自分の意思は上手に伝えていな かったんじゃないかな。今は、そういう風にしてます。中国語でも。

FJ2-2 催し物の参加者にアポイントをとるときに、上司から「予定参加者名はまだ相手側に言わないように」と言われたんだと思う んですが、それが分からなくて、言ってしまい、上司が困りました。

JJ に面接調査をしているときによく「ビジネス日本語教育ではビジネススキルについて教えない のですか」と聞かれる。ビジネス日本語教育の内容と、ビジネススキルや最近よく耳にする社会人 基礎力にはどんな関係があるか。ビジネス日本語教育の内容を整理するにあたり、ビジネススキル のうち何を、どのように言語教育として教えるのか明示していくことが今後必要な作業となろう。 


\section{粟飯原 志宣：接触場面における香港の日本語学習者の意識 \\ ービジネス接触場面において学習者が感じた問題を中心に一}

\subsection{5 対照言語行動「認識の違い」に起因する問題（34.8\%）}

言語行動や異文化理解に関する意識は、アンケート調査結果では $16.9 \%$ とかなり低いが、面接調 查の結果では 2 倍強の $34.8 \%$ となっている。筆者はここに分類された 23 件を、大きく以下 8 点の 「認識の違い」に起因すると考えた。件数の多い順から、(1)職務範囲（6 件）、(2)評価の表現方法 / 理解の仕方（4 件）、(3)謝罪の意味（3 件）、後はすべて同位（2 件）の（4)業務上の価值観、(5)ビジ ネスコミュニケーション上の定型表現、(6)曖昧さの理解、(7)マナー、8)待遇表現とした。言語行動 にまつわる問題は、言語行動の相違ではなく個性・人格の問題として片付けられてしまうケースも 見受けられる。こうした誤解を避けるためにも、まずFJ の言葉から何が言語行動の相違に起因する 問題であるかを発見し、次に原因となる「違い」を特定するために詳細な分析が必要となる。

(1)職務範囲の認識の相違

ここには、自分の請け負った職務範囲、責任範囲の認識が J J F F では異なるために起こる問題 が分類されている。「職務範囲の認識の相違」自体は一見言語とは関係がないように思われる。し かしこの認識の違いから、言語行動に大きな違いが生まれ、JJ と FJ 共に理由が分からないままに 問題が進行していく過程が窥われる。

FJ3-8 一つのことがいろいろなやり方があるんじやないですか、多分結果としては同じなんだけど、やり方が違っていて結果が同じ であれば、いいだと思うんですね。ただ時々、同僚の上司がそのやり方がちょっと違ったら怒るんです。なんでこういう風にやったん ですか。こういう風にやらないんですか。なんかあったんですか。どうしてこんなになっちやったんですかって聞くんです。でも結果 としては同じですよ。

FJ3-8 はよくFJ から聞かれる職責についての問題である。香港では請け負った仕事は遂行方法も 自由裁量が与えられ、最終段階まで自己完結させるものだと考えられているようであるが、こうし た考え方のもとでは、相談や中間報告は「分からないから教えを乞う＝自分に処理する能力がない =業務遂行能力が低い」ことの露呈を意味する。そのため問題が発生しても最終的な結果がでるま で、相談や中間報告が行われないケースが多いと聞く。であるから FJ 3-8 も自分の同僚の話とはい え、任されたと考えていることに対する逐一の報告義務には、業務能力を疑われているようで納得 がいかないようである。

(2)評価の表現方法／理解の仕方

部下の成長を願って行った忠告や助言が、常にありがたく受け入れられるとは限らない。それだ けではなく忠告・助言を「怒られた＝低い評価」と解釈し面子をつぶされたと憤慨する場合もある ようだ。以下のケースがそれにあたる。職務範囲に対する責任ということと深く関連するが、FJ313 にあように、業務ができることを前提に対価としての給料が払われているという理解のもとで は、できて当たり前で、それをわざわざ褒める必要はなく、逆になにも言われないということが、 肯定的な評価を意味する。 
FJ3-9 正しくやっていたんですけど、でも時々、上司が自分で誤解して怒ったんです。正しくしていたんですよ。でも怒ったんです 。怒ってすごく大きな声で話してて、その人の目の前で怒って、で、その後に自分が悪かったって思ったら「あ、すみません。さっき はごめんなさい」でも、もう怒ったんですよ。その後にお詫びしてもしょうがないと思う。怒ったんですも。

FJ3-13【期待できない人には注意しないという話題で】ちょっと考え方が違うかもしれませんね。香港人にとっては、何も言わないの が褒める事なんだと思う。あなたができるのがあたりまえだと思っているから、できても当然だと思うんですよ。（じや、期待以上を しても?）言わないと思います。

FJ3-12 【アドバイスを受けるときに抵抗があるという話題から】香港の人の方が日本人よりプライドが高いんですよ。

こうした考えを基礎にする部下に、「共に成長しよう」と言った部下の成長を望んでの忠告や助 言でも、能力が満たないと判断されて「怒られた＝低い評価」と解釈されてしまう。

また FJ のほうも忠告や助言に対して「原因を見つけて弁解する」という相手の善意を拒否する言 語行動をとることになってしまう可能性もある。また、何も言われないのが肯定的な評価だとした ら、FJ3-9 のように、上司の誤解がもとで「怒られる＝低い評価」を人前で公示されたことによる 精神的ダメージは、誤解が解け、個人的に謝られたとしてもなかなか瘉されないだろう。以上のよ うな背景から FJ3-12 のように、忠告や助言、指導の受け入れ方が日本人とは異なる香港人をよく 「プライドが高い」と表現するが、筆者は自尊心の高さではなく、責任範囲の解釈と評価の違いに 起因していると考えている。

(3)謝罪の意味の違い

$\mathrm{JJ}$ から「問題が起きたなら、迷惑を受けた側に謝罪すべきなのに、現地スタッフはなかなか謝ら ない」という声を良く耳にする。この話を日本語が堪能な中国人にすると「自分が故意に起こした 不都合ではない。いろいろな事情があって起きたことなのだから、その説明を第一にすることは当 然だと思う」と言われる。双方の言い分は最もであるが、謝罪のあり方になぜこのような違いが生 まれるのか、下記の事例から考えてみたい。

FJ1-4【日本語の謝罪が英語や中国語と違うことを少し説明した後】あつ、そうなんですか。知りませんでした。だから、こちらの 責任じゃなくても、謝っておく‥ああ。メールが来ても、一切謝っていなかった。たぶんそうだと思う。だから関係悪いです、お客さ んと。多分そうです、なんかむこうが[記入した]フォームが間違っているのに、なんでむこうが怒るのっていう感じで、謝らなかった んです。‥だから関倸悪くなったんだ…多分‥これは本当に知らなかったんです。日本人はよくごめんなさいを言うのは、知ってる んですけど、なんかこういうときも言うんですかって言う…そ机は初めて聞いたんです。最近は、日本語と英語と日本人の揢さんと やりとりしてま寸ので、多分英語も日本語も、謝ることはまず少ないです。書きたくないと言うより、書くと自分のせいになっちやう ので、[お客さんは]もう怒っているので、謝ったらもっと怒るのじゃないのかなと思っていました。多分ね、私たちはずっと「あなた はこれが間違っているよ。間違ってる!」とずっと言っているから。英語は分かりませんけど、中国語だと自分が謝ると、頭を下げた 、なんと言うか、（面子がなくなる?）というか、取り引きと同じで、立場は同等のはずです㱛、協力関係。謝ると [立ち場を]下げま す。だから同じ立場じやなくて、なにか人に要求があっても絶対あわなければなりません。そういう感じがします。

日本語では責任の所在は別として、相手が被った不都合は分かったという意味で謝罪の言葉を使 うことがある。それに慣れていると、香港では謝罪がないという印象を受けることが多い。面接調 査では、謝罪を躊躇する理由が具体的に挙げられている。謝罪をすると「自分のせいになる／相手 がもっと怒る/あなたは間違っていると言われ続ける／対等であるはずのビジネス関係が崩れる」 という。他言語で業務に携わる場合は、母語との謝罪の意義の違いを知らなければ、意図せぬ「不 遜な態度」という誤解を受けかねない。 


\section{粟飯原 志宣：接触場面における香港の日本語学習者の意識}

ービジネス接触場面において学習者が感じた問題を中心に一

はっきりと文句を言うので、対処方法を考えられる。でも日本の取引先は「わかりました」だけだ ったので、本当に考えていることは分からなかった」と語っている。はっきりことばで語ることが 意思表示である文化背景をもつ者と、文脈から相手に気づいてもらう方法で意思を表示する者との 異文化間交涉では、誤解が生じる可能性がとても高い。

(7)マナーにおける行動規範のちがい

日本のマナーにおける言語行動規範の変遷を調查した増田（2008）では、マナーにおける言語行 動規範には「聞き手に対する影響」と「話し手の評価」があると述べている。香港の一般的な行動 規範から見た場合、日本のマナーをどのように見えるのであろうか。また学習者から「ビジネスマ ナーはありません」とよく聞かれることは事実なのであろうか。

FJ2-8日本のマナーは常に他人のことを考えなければならないので疲れます。例えばバッグを持っているだけでも、周りの人のこと を考えなければならないから。

FJ5-2 香港人同士でも、結構礼儀正しくしないと、無視されますね。

FJ5-2 T゙は、マナーはないといわれる香港でも、聞き手を価值ある者として認めている言語行動 をとらなければ、聞き手から交流相手として認めてもらえず無視されると語っている。聞き手の面 子に関わる「聞き手に対する影響」が言語行動規範となっている典型的な例で、話し手中心のよう に考えられがちな香港にも聞き手の感情に考慮するマナーが存在すること、また交流相手として認 めてもらうために言語行動を選択寸るという「話し手への評価」も規範にあることが窥える。FJ2-8 では、日本では常に他人を意識して配慮しなければならないので疲れると言っている。日本ではバ ックを持った時点でぶっからないようにと見えない相手に配慮し始め、香港の人はぶっかった時点 で、対処すればいいと考えているのではないかと語る。これらの事例から、日本も香港も「聞き手 への影響」と「話し手の評価」がマナーにおける言語行動規範になっているという点で共通するが、 「見えない不特定多数の相手（公衆）に対する事前の配慮」の有無という点では大きく異なる。

(8)待遇表現

ここでは、ある音声や言語行動に対する解釈が異なるため、JJ と F J の間に意図せぬ距離感や誤 解、引いては相手の性格や品位を疑うといった可能性を生む例が挙げられている。

下記 FJ4-1 では、自称の選択を巡って議論が交わされている。FJ4 の勤める業界ではもともと硬 い表現が好まれているということであるが、30 代の日系ブラジル人であるFJ4 の上司は、日常会話 
では使われない「小職」「小生」という謙称を好み、社内メールでも使用しているという。この謙 称は元来改まった表現であり、ある業界あるいは比較的年齢の高い層ではまだ好まれているようだ が、筆者はこれを謙称を用いた一種の「仲間意識」の形成なのではないかと考えている。したがっ て、FJ4 やその先輩 JJ のように、社内における謙称の使用に、「仲間意識」を見いだせない場合は 距離感、違和感を感じることになる。

FJ4-10【携わっている業界では、取引先、本社に対してメールで固い表現を好むという話題から】本当にたまに、小生とか小職とか書 いてます。メールに。だから、たまにその件は私にも関倸あるから、例えば上司のKさんが小生とか小職とか使ってメール返事して、 で、本社からなんとか返事して、で、私途中で回答する必要があるとき、ちょっと悩んでしまう時が、私も小生とか使うべきかなと。 この場合は特にKさんがいないときに、私が代わりに回答するときに、まあ、初めに「横からすみません」と、「Kが出張中なので、小 職がかわりに返答します。」（「わたくしFが」のほうがいいかな）その避け方の方がいいですよね。（JJ：そうです、距離感。感じ ま寸よ叔。同じ会社なのに使わなくていいじゃないかとか）（まだ私たち親しくないのねという感じ） (爆笑)

\section{3 アンケート調査から得られなかった内容}

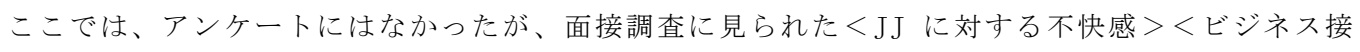
触場面の背景 $><$ 教育的補助への期待 $>$ という 3 つの項目について考察する。

\subsubsection{JJに対する不快感（15.2\%）}

面接調查では、ある程度の運用能力を付けた FJ がビジネス接触場面において不快と感ずる JJ の 言動について述べている。これらは、日本語母語話者が非日本語母語話者と日本語で話す時に配慮 しなければならない項目として有効な情報となろう。ここに分類された 10 件は大まかに(1)日本的企 業文化の押しつけ、(2)待遇表現関連、(3)「日本人に代わって」は不快、という3つに分け、内容別 にFJ の不快感の原因を探る。なお、ここに分類された内容、特に(2)にはJJの言い方に対し不快感 を感じたというように言語行動の待遇表現に分類できる内容も多い。しかしアンケートでは得られ なかった「FJ が JJ に対して不快感を感じる」という点に着目し、この項目を設定し敢えて独立さ せた。

(1)日本的企業文化の押しつけ

FJ2-9 前の上司は忙しい人だったが、小さいことは言わなかったんですが、今の上司は細かい。例えば「 9 時着席、朝食は其の前に 終わらせること」といらメモが回しました。みんな嫌がっています。

海外進出における現地化の需要性や日系企業における問題は飯田（2007）に詳しい。本研究 FJ29 にも、海外駐在経験の長い凄腕駐在員が香港の一般的な働き方に対する配慮なしに、日本的な就 業規則を強制し、オフィス全体からひんしゅくを買っている事例がある。現地スタッフに効率よく 働いてもらい実利をあげるために働く環境をどのように整えるかは重要な点である。一般的にこれ 


\section{粟飯原 志宣：接触場面における香港の日本語学習者の意識 \\ ービジネス接触場面において学習者が感じた問題を中心に一}

まで日系企業は駐在員制度を導入し、現地化よりも現地法人の日本化を選んできたように見えた。 現地生産においては日本的なやり方を導入することで品質や効率をある程度確保でき、日本の本社 が現地の働き方を理解する負担を減らすことができたからである。しかしそのような一方的なやり 方は、この事例のように明らかに社員全体の土気をさげ、最終的には現地法人全体の収益性を下げ る。人材派遣の話によると最近は現地化を進める日系企業も増えているそうである。賃金体系、就 労規則、人事制度などの現地化はわかりやすい。しかし 4.1 .5 対照言語行動で述べたような「働き 方」を左右する考え方、価值観などを理解した上での現地化でなければ意味がない。

(2)待遇表現関連

ここでは、日本人の待遇表現に対するFJ の不快感や失笑について語られている。

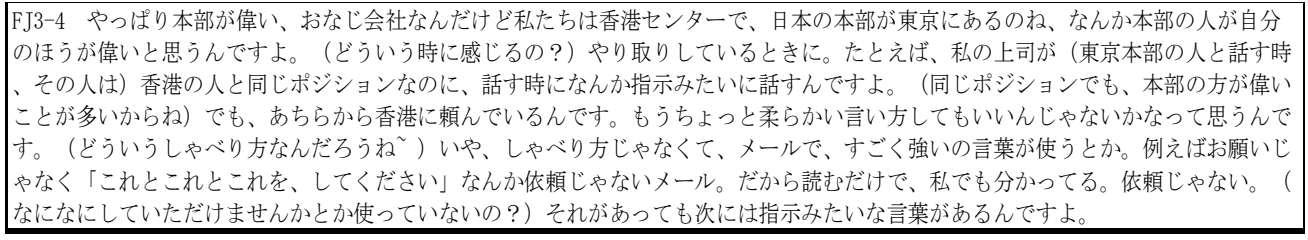

FJ3-4 日談では、「一するように」が使用されていたとのこと）であることに不快感を抱いている。他に も、JJ としては重要事項を誤解されずに理解してもらおうと、はっきりわかりやすい日本語で書い たつもりだが、ある程度待遇表現を身につけている FJ には、急にスピーチレベルが変化することで $\mathrm{JJ}$ が怒っているのではないかと FJ に不安を与える例も見られた。FJ の待遇表現の不適正さについ て触れる JJ は多いが、JJ も FJ に対する待遇表現には十分配慮しなければ、双方の人間関係に距離 感を生みかねないことがわかる。

(3)「日本人に代わって」は不快

海外旅行等で、その国の言葉や、相手の話す日本語が分からず目的が達成できない時に「自分の母 語で話したい」と思った経験があるだろう。これは旅行好きな香港の学習者は十分に理解している と思われる。しかし業務においてはどうであろうか。FJ1-5 F F 自身が担当者であるにも関わらず、 日本人から「日本人に代わって」と言われ、それを容認できずに、不快感を示している事例である。 
FJ1-5（日本人のカスタマーサービスはたいいんですか）前の会社はもっと大変なお客さんだったので、今はもっといいと思います。 前は日系の商社だったので大変でした。私はマーチャンダイザーだったんですが、お客さんは40代の男性で、香港の女の子、というか 女の子は仕事ができないと思っていたんですよ。私もそのときは新卒だし、私の言ってることはあまり信じてくれないんで大変だった んですよ。なにも信じてくれなかったので、直接上司に言って[代わっての意]って言われたんです。たぶん上司も同じことを言ってる んですけど、そのお客さんは「はい。分かりました」つて

仕事では誤解は許されないので、旅行以上に確認が必要になる。非日本語母語話者と話している 日本人は、念のためにも日本語母語話者との確認を要求する。特に FJ の日本語能力がまだ安定して いない新卒時や助詞に問題がある場合は、確認が入っても当然であろう。しかし事例では業務上の 確認行動を容認する代わりに不快感が全面にでるのは、会社の上司や同僚に代わられているからで はないだろうか。日本人の「母語話者に確認を取りたい」という気持ちへの理解より先に、FJには 自分の日本語能力の低さ、あるいは信頼性への明らかな低い評価と映り、それが上司や同僚に報告 されたという気持ちが働いていることが不快感の原因であろうと推測される。

\subsection{2 ビジネス接触場面の背景（10.6\%）}

ビジネス接触場面の背景である(1)職場と (2)社会について触れている事例を見て行く。

(1) 職場（日系企業）について

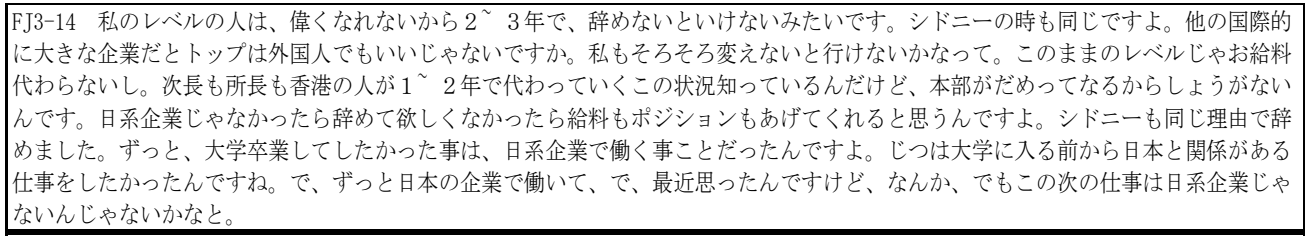

ここからは、日系企業の雇用方針の影響を部分的に窥うことができる。日本語ができると初めは 就職しやすく、比較的に給料も高いが、昇級・昇給に制限があるので上昇志向の強い者は日系企業 から逃げ出すという。これがすべての日系企業に当てはまるとは限らないが、一般的にそのような 印象があるとすれば、優秀な海外の人材を採用し、長く有効活用することは難しい。こうした雇用 方針の影響は、他にも「出世は期待できないが、現在の職責、報酬に満足できるなら、あまり仕事 をしなくても首にならず、香港の企業より福利厚生が整い安定しているので楽」という意識や、

「すぐ替わるトップに慣れるまでに時間がかかり非効率」や、現地化を望む現地スタッフの声など にも窥える。

日系企業について FJ が意識する内容に関して、我々日本語教師が直接働きかけることは難しいか もしれない。しかし、学生を企業に送り出す側として、知っておくべき事項であり、ビジネス日本 語教育における日本事情や日本文化としてしっかり伝えるべきだろう。 


\section{5. まとめと今後の課題}

本稿では、ビジネス日本語教育現場の改善を提言するために、面接調査により得られた香港のビ ジネス接触場面における非母語話者 5 名の意識 66 件を、粟飯原（2008）のアンケート調查の分類を 参考に 9 項目に分類し、詳細に考察した（紙面の制限上掲載できた分析は 66 件のうち 30 件）。そ の結果、学習者は基礎的言語能力の強化と言語行動に関する問題解決を必要としていることが窺わ れた。また、待遇表現の面でFJ $F J J に$ 対して不快感を抱いていることも明らかになり、今後 FJ と 向き合う JJ に必要な警鐘となろう。また、粟飯原（2009）に見られた J J と F J の言語行動に関す る問題意識の「ずれ」は、面接調査の結果を加えて考察し直すことで、F J の数值が JJに近づいた。 これは、アンケートでは具体的に表出されなかった FJ が意識した問題の内容が面接で明確になり、 その原因の多くが言語行動に関わるものと分かったからだ。言い換えれば、双方の言語行動に対す る「気づき」が起これば、問題意識の「ずれ」は解消に向うことが示唆されているのではないか。 ビジネス日本語教育現場の改善を進めるためには、JJ と F J の問題意識を擦り合わせ、「ずれ」 の具体的内容を場面毎に明確にし、 J J と F J 双方に対する言語行動を選択する能力を養成するため の教材作成と、教育実践を重ねることが今後の大きな課題である。

\section{6. 終わりに}

接触場面において我々は、無意識に、母語を話す社会での常識を判断基準にしがちではないだろ うか。同様に学習者が意識する問題も、その母語文化における価值基準がもとで起きているのでは ないだろうか。こうした社会的な価值観の相違に起因した問題は、JJ と FJ の心理的距離を増大さ せる要因となり、人間関係という仕事をする上で最も大切な基盤を脆弱にする。これを解決するに は、双方がどのような価值観のもとに、どのような事柄に対し、どのような言語行動を取るのかと いう実証研究が必要である。本稿の調査と考察は、少しでも相互理解が進むように、まずFJ の立ち 場で考えてみようという努力であった。

学習者が職場で感じている問題を言語教育の面から解決の糸口を見つけたいという思いのうちに、 各事例を分析する筆者の解釈には、ややするとすべてを言語に結びつけようとする意図が感じられ るかもしれない。実は、単に個人的な性格が原因で起きた事例やたまたまFJ が精神的に落ち込んで いて、すべてを悪く解釈してしまっただけのことかもしれない。筆者は試みた解釈が必ずしも正し いと思っているわけではない。また、5人だけの資料で香港の FJ の問題意識を一般化しようと目論 んでいるわけでもない。筆者の願いは、この拙論が「学習者やFJ の言語行動を捉えるときのヒン ト」あるいは「学習者やFJ は日本語母語話者の言語行動をこんな風に解釈しているかもしれない」 と考えるきっかけとなり、更に深い研究のたたき台になればと思うところにある。 


\section{粟飯原 志宣：接触場面における香港の日本語学習者の意識 \\ ービジネス接触場面において学習者が感じた問題を中心に一}

\section{注}

本稿においては表 4 に示したような分類項目が始めからあったわけではなく、66 件の基礎デ 一タを似た内容や何に対する意識なのかで取りまとめ、それから名称を付けるという手法をとっ た。具体的には、基礎データをカードに書き込み、机の上で似た内容を集めて、グルーピングし た。この概念を更に大きなカードにして問題の対照を考えると、6つのカテゴリーができ、概念 名をつけた。こうした実際の分類過程の作業は KJ 法に近く、6つの項目に概念名をつける過程 は修正グラウンデット・セオリーを参照にしている。

\section{参考文献}

粟飯原志宣（2008）「ビジネス接触場面における日本語母語話者と学習者に生じる問題一ビジネス 日本語教育現場の改善のために」大阪大学大学院言語社会研究科修士論文

（2009）「ビジネス接触場面における日本語母語話者と学習者に生じる問題一海外で日本 語を使用する日本語母語話者の視点を探る-」『間谷論 (3)』pp. 49-77.

（2012）「ビジネス接触場面における日本語母語話者の問題意識一使用言語の違いから 見る問題意識の共通点と相違点一」『早稲田日本語教育学』第 11 号 飯田謙一（2007）「海外日系現地企業の経営管理と現地人従業員の働くことや企業に対する意識-現 地における調査結果をもとにしてー」『専修商学論集』第 84 号 pp. 1-55

木下康仁（2003）「グラウンデッド・セオリー・アプローチの実践」弘文堂

近藤彩（1998）「ビジネス上の接触場面における問題点の関する研究一外国人ビジネス関係者を対象

にしてー」『日本語学育』第 98 号、pp.97-108. 日本語教育学会

清ルミ（1998）「外国人社員と日本人社員：日本語によるコミュニケーションを阻むもの」『異文 化コミュニケーション研究』Vo1.10、pp. 57-73. 神田外語大学

増田祥子（2008）「ことば遣いに関するマナー本に見る言語行動規範の変化」第 23 回メディアとこ とば研究会（2008 年 12 月 13 日）発表資料

宮副裕子（2003）「多言語職場の同僚たちは何を伝え合ったかー仕事関連外話題における会話上の 交渉一」『接触場面と日本語教育ーネウストプニーのインパクトー』宮崎里司・ヘレンマ リオット編 pp165-184 明治書院 